\title{
Interaction between single wall carbon nanotubes and a human enteric virus
}

\author{
Anna Rita Petrinca ${ }^{a}$, Domenica Donia ${ }^{a}$, Rosadele Cicchetti ${ }^{c}$, Federica Valentini $^{\mathrm{b}}$, \\ Gabriella Argentin ${ }^{c}$, Marilena Carbone ${ }^{b}$, Antonio Pietroiusti ${ }^{d}$, Andrea Magrini $^{d}$, \\ Giuseppe Palleschi ${ }^{b}$, Maurizio Divizia $^{a, *}$ \\ a University of Tor Vergata, Faculty of Medicine, Dept. Public Health, Hygiene chair, Via Montpellier, 1, 00133 Rome, Italy \\ ${ }^{\mathrm{b}}$ University of Tor Vergata, Faculty of Chemistry, Dept. Science and Chemical Technology, Italy \\ ${ }^{c}$ University of Tor Vergata, Faculty of Medicine, Dept. Public Health, Biology Lab, Italy \\ ${ }^{\mathrm{d}}$ University of Tor Vergata, Faculty of Medicine, Occupational Medicine, Italy
}

\section{Article history:}

Received 12 October 2009

Received in revised form 30 March 2010

Accepted 30 March 2010

Available online 8 April 2010

\section{Keywords:}

Single wall carbon nanotubes

Polyethylenimine

Hepatitis A virus

Real-time reverse

transcriptase-polymerase chain reaction

\begin{abstract}
A B S T R A C T
Activated single wall carbon nanotubes have been used for biomedical purposes as carriers for drugs, peptides, proteins and nucleic acids. A large volume of data speaks to their suitability to act as a carrier. The ability of two differently activated SWNTs (with carboxyl groups or with carboxyl groups and polyethylenimine (PEI)) to form a complex with the hepatitis A virus was evaluated. Both types of activations permitted the formation of a virus-SWNT complex. However, their patterns were different. The carboxyl-activated nanotubes had a somewhat low adsorptive capacity that was related inversely to the concentrations of the SWNTs and viruses. Statistical analysis, using the $\chi^{2}$-test, showed no significant differences between the SWNT-PEI ratios of $1: 2.5,1: 1$ and $1: 0.5$. The addiction of PEI improved the adsorption, probably because of the electropositive charge of the molecule. Adsorption was optimal between $100 \mu \mathrm{g}$ and $10 \mathrm{ng}$ with a SWNTs-PEI weight ratio of 1:0.2 up to an inoculum of $10^{5}$ genome equivalents of hepatitis A virus. Reducing or increasing this weight ratio reduced the adsorptive capacity of the PEI, and this adsorption activity was time and contact-dependent. Thus, SWNTs coated with PEI are able to complex with viruses, and they might be used in the future to transfect non-permissive cell lines.
\end{abstract}

(c) 2010 Elsevier B.V. All rights reserved.

\section{Introduction}

Single wall carbon nanotubes (SWNTs) are a stable material with unique chemical, physical and mechanical properties. They are insoluble in any type of solvent, unless they are activated by the non-covalent or covalent addition (Klumpp et al., 2006) of a chemical group to improve biocompatibility and biomolecular properties (Shim et al., 2002). In this condition, they can be used to uptake various molecules such as drugs, proteins and nucleic acids (Kam et al., 2004; Cai et al., 2005) for in vivo and in vitro delivery. Recently, Brady-Estevez et al. (2008) used single-walled carbon nanotubes to remove viruses and bacteria from water.

Polycationic polymers have been used as functional groups. Among them, polyethylenimine (PEI), which can be of either low or high molecular weight, is one of the most versatile agents (Boussif et al., 1995) for delivery. Its efficiency depends both on the size of the polymer, and on the cytotoxicity associated with the total charge (Fischer et al., 1999). The high molecular weight PEI has a

\footnotetext{
* Corresponding author. Tel.: +39 06 72596119; fax: +39 062025285

E-mail address: divizia@uniroma2.it (M. Divizia).
}

higher transfection efficiency than the low molecular weight version, but it displays dose-dependent cytotoxicity (Nimesh et al., 2006).

The ability of SWNTs, activated with either carboxyl groups and PEI or with carboxyl groups only to withdraw hepatitis A virus (HAV) from a cellular lysate was investigated. In the future, activated SWNTs could be used to transfect non-permissive cell lines or to pick up viruses from different environmental matrices.

The interaction between the SWNTs and the enteric virus (HAV) was demonstrated by direct RT-PCR and quantified with respect to the HA viral control by qRT-PCR.

\section{Materials and methods}

\subsection{Chemicals}

SWNTs activated with $\mathrm{COOH}$ groups (purity, >90 wt\%; diameter, $1-2 \mathrm{~nm}$; length, 5-30 $\mu \mathrm{m}$; surface area estimated by the BET (Brunauer, Emmett, and Teller) method, $407 \mathrm{~m}^{2} / \mathrm{g}$; and functional $\mathrm{COOH}$-content $2.73 \mathrm{wt} \%$ ) were purchased from Cheap Tubes (Brattleboro, VT, USA). Branched polyethylenimine (PEI, average 
Mw 25,000) was purchased from Sigma-Aldrich (Milan, Italy) and used without any further treatment. $\mathrm{Na}_{2} \mathrm{HPO}_{4}, \mathrm{NaH}_{2} \mathrm{PO}_{4}$, EDC (1ethyl-3-(3-dimethylaminopropyl) carbodiimide hydrochloride), $\mathrm{KCl}$ and ethanol were of analytical grade and were purchased from Sigma-Aldrich (Milan, Italy). Sodium hydroxide pellets were used for $\mathrm{pH}$ adjustments. Diluted solutions were prepared just before use. The $\mathrm{pH}$ of the solutions was adjusted with either $0.1 \mathrm{M} \mathrm{HCl}$ or $0.1 \mathrm{M} \mathrm{NaOH}$.

\subsection{Preparation of the carboxylated carbon nanotube PEI nanocomposite (SWNT-PEI)}

Following the chemical activation of the $\mathrm{COOH}$ groups on the walls of the SWNTs by EDC (1-ethyl-3-(3-dimethylaminopropyl) carbodiimide hydrochloride), the SWNT-COOH was further activated with PEI, thus yielding SWNT-COOH-PEI nanocomposites $(1: 2.5 \%(\mathrm{w} / \mathrm{w})$ is called SWNT-PEI $2.5 ; 1: 1 \%(\mathrm{w} / \mathrm{w})$ is called SWNT-PEI $1 ; 1: 0.5 \%(\mathrm{w} / \mathrm{w})$ is called SWNT-PEI 0.5 and $1: 0.2 \%(\mathrm{w} / \mathrm{w})$ is called SWNT-PEI 0.2). Subsequently, these nanocomposites were dispersed in DMEM 1\% FCS culture medium (Dulbecco's Modified Eagle's Medium with $1 \%$ foetal calf serum) for the molecular tests and in EtOH solution for morphological characterisation by TEM at the concentration of $1 \mathrm{mg} / \mathrm{ml}$ using an ultrasonic bath for $30 \mathrm{~min}$ at room temperature.

\subsection{SWNT dispersion for experiments with $H A V$}

SWNTs activated with $25 \mathrm{kDa}$ PEI or carboxyl groups were dissolved in DMEM (Dulbecco's Modified Eagle's Medium) with 1\%FCS (fetal calf serum) (Sager et al., 2007) at a final concentration of $1 \mathrm{mg} / \mathrm{ml}$ by sonication in an LBS1 ultrasonic bath (FALC Instruments, Bergamo, Italy) for $2-3 \mathrm{~h}$ before each virus-based test. Different amounts of HAV were added to this homogeneous and stable dispersion, and HAV was allowed to conjugate with the SWNT-PEI and SWNT-COOH at room temperature.

\subsection{Human hepatitis A virus}

HAV (strain HM175 kindly obtained from A. Bosch, Dept. of Microbiology, University of Barcelona) was cultured in a FRhK (fetal rhesus monkey kidney) cell line. Briefly, confluent monolayers growing in Nunc flasks $\left(175 \mathrm{~cm}^{2}\right)$ (Milan, Italy) were infected with $5 \mathrm{ml}$ of HAV at $1 \times 10^{5}$ gen equiv./ml. After 1 h of adsorption at $37^{\circ} \mathrm{C}$, the inoculum remained and $25 \mathrm{ml}$ of fresh medium was added. At 90-95\% of the cytopathic effect (CPE), the cells were frozen and thawed. The suspension was treated with $20 \%$ of chloroform to destroy the clumps of virus and was titrated by qRT-PCR.

\subsection{Adsorption of viruses onto SWNTs}

One hundred microlitres of viral suspension in DMEM 1\% FCS at the indicated concentration was mixed in ice with $100 \mu \mathrm{l}$ of SWNT-PEI or SWNT-COOH at different concentrations. The mixture was washed gently three times with DMEM $1 \%$ FCS by centrifugation with a bench Eppendorf centrifuge at $14,500 \times g$ for $5 \mathrm{~min}$ at room temperature. Each experiment was performed three times.

\subsection{Chemical apparatus}

SWNT-PEI 0.2 conjugated with HAV and HAV alone (viral control) were characterised by a $100 \mathrm{kV}$ High-Resolution Scanning Transmission Electron Microscope (HRTEM) using a TEM Philips (CM120, with LaB6 as filament). For the TEM investigation, the SWNT-PEI 0.2-HAV nanocomposite was dispersed previously in ethanol ( $1 \mathrm{mg} / 5 \mathrm{ml}$ ) using an ultrasonic bath for $1 \mathrm{~h}$ at room temperature. Following the same procedure, an HAV solution was prepared in ethanol and used as a control. A perforated carbon Formvar film supported by copper grids ( $3 \mathrm{~mm}$ ) was dipped into the SWNT-PEI 0.2-HAV and HAV control for a few seconds. The solvent was evaporated subsequently with an IR lamp.

\subsection{Virus detection by reverse transcriptase-polymerase chain reaction ( $R T-P C R)$}

Viral RNA was extracted from pellets using the Trizol-LS reagent (Invitrogen, Milan, Italy). The final RNA was collected in $20 \mu \mathrm{l}$ of sterile RNA-DNase free water (Invitrogen, Milan, Italy); $10 \mu$ l was reverse transcribed immediately, and the total cDNA was amplified using specific primers designed from the VP1-VP2 region of the viral genome by OligoExplorer 1.2 software: HAV-F: 5'-TGA ACA GGT ATA CAA AGT CAG C-3', position 2017-2038 of the human hepatitis A strain (accession number M14707); HAV-R: 5'-ATA CCA ACT TGG GGA TAT GGA AC-3', position 2281-2259. Primer HAV-R at a concentration of $1 \mu \mathrm{M}$ was used in an RT reaction in $30 \mu \mathrm{l}$ (final volume) containing $4 \mathrm{U}$ of AMV Reverse Transcriptase (Promega, Milan, Italy), $20 \mathrm{U}$ of Recombinant RNasin Ribonuclease Inhibitor (Promega, Milan, Italy), each deoxynucleoside triphosphate at a concentration of $0.2 \mathrm{mM}$ and $10 \mu \mathrm{l}$ of denatured $\left(5 \mathrm{~min}\right.$ at $95^{\circ} \mathrm{C}$ ) RNA samples. The reaction mix was incubated for $30 \mathrm{~min}$ at $42^{\circ} \mathrm{C}$. The RT product was processed by PCR using $2 \mathrm{U}$ of GoTaq Flexi DNA Polymerase (Promega, Milan, Italy) in a $100 \mu$ l mixture, supplemented with each primer at a concentration of $0.5 \mu \mathrm{M}$, each deoxynucleoside triphosphate at a concentration of $0.2 \mathrm{mM}$ and $\mathrm{MgCl}_{2}$ at a concentration of $2 \mathrm{mM}$. The PCR program included a 3 min denaturation step at $95^{\circ} \mathrm{C}$ and 45 cycles of amplification for $30 \mathrm{~s}$ at $95^{\circ} \mathrm{C}, 30 \mathrm{~s}$ at $55^{\circ} \mathrm{C}$ and $30 \mathrm{~s}$ at $72{ }^{\circ} \mathrm{C}$, followed by a final elongation step of $5 \mathrm{~min}$ at $72^{\circ} \mathrm{C}$. The PCR product of $265 \mathrm{bp}$ was loaded on a $2 \%$ agarose gel containing $0.5 \mu \mathrm{g} / \mathrm{ml}$ of ethidium bromide and then photographed under UV light.

\subsection{Virus titration by real-time RT-PCR ( $q R T-P C R)$}

The HAV titre $\left(2.7 \times 10^{4}\right.$ copies/ $\left.\mu \mathrm{l}\right)$ was obtained by qRT-PCR using SYBR Green I chemistry and following an in house protocol. Armored RNA Hepatitis A Virus (Ambion Diagnostic, USA) was used as a standard to generate a calibration curve from 10 -fold dilutions of the initial standard (Donia et al., 2006). Once HAV was quantified, extracted and purified viral RNA was used to generate a standard curve to determine viral adsorption in SWNT tests (the second standard curve). The primers were the same as those used for RT-PCR and were reported previously. Syber Green I real-time one step RT-PCR was carried out in a $25 \mu$ l reaction volume with a BioRad iCycler. Five microlitres of extracted RNA were assayed in three replicates containing $20 \mu \mathrm{l}$ of the master mix supplied with the kit (QuantiTect Syber Green I RT-PCR kit, Qiagen, Hilden, Germany), added to $0.4 \mu \mathrm{M}$ each of the forward and reverse primers. After reverse transcription at $50^{\circ} \mathrm{C}$ for $30 \mathrm{~min}$, Taq polymerase was activated at $95^{\circ} \mathrm{C}$. Amplification was undertaken for 45 cycles consisting of a denaturation step at $94^{\circ} \mathrm{C}$ for $15 \mathrm{~s}$, annealing at $55^{\circ} \mathrm{C}$ for $30 \mathrm{~s}$ and an extension step at $72^{\circ} \mathrm{C}$ for $30 \mathrm{~s}$. The threshold cycle values generated by the iQ analysis software were used to calculate a linear regression line by plotting (on a graph) the logarithm of the starting copy number, expressed as increasing fluorescence values from the standard dilution amplification. The slope of the standard curves determined the PCR efficiency (EFF). The reproducibility of the qRT-PCR was indicated by correlation coefficients (CC) with values ranging between 0 and 1 (Donia et al., 2005). A melting curve protocol was used to determine the specificity of amplification. The presence of a single melting temperature peak indicated a specific product $\left(79 \pm 0.5^{\circ} \mathrm{C}\right)$. 


\subsection{Statistical analysis}

All the statistical analyses were performed using the $\chi^{2}$-test at www.graphpad.com.

\section{Results}

\subsection{Z potential measurements}

The conjugation of nanotubes with PEI may lead to a composite material characterised by simultaneous covalent amidic binding between the nanotubes and the polymer as well as and partial positive charge on the surface due to the ammonium heads of the side branches, which do not interact with the carboxyl groups. As confirmed by $\mathrm{Z}$ potential measurements, the composite has a positive charge: SWNT-COOH: $-42.2 \pm 0.5 \mathrm{mV}$, SWNT-PEI 2.5 $+18.6 \pm 0.2 \mathrm{mV}$ and SWNT-PEI $2.5-\mathrm{HAV}+16.5 \pm 0.3 \mathrm{mV}$ (personal data). The resulting charged surface is able to conjugate the negatively charged HAV molecules by electrostatic interactions. The overall charge, however, remains positive at least for the samples with a high load of PEI because, in such cases, the polymer is used in excess.

\subsection{TEM}

TEM micrographs of HAV alone (viral control) and upon conjugation with the SWNT-PEI 0.2 are reported in Fig. 1a and b, respectively. Fig. 1a shows the typical spherical shape of HAV clusters in ethanol, with diameters ranging from 40 to $200 \mathrm{~nm}$. The smaller particles (around $40 \mathrm{~nm}$ in diameter) represent $\approx$ two HAV particles (considering that a single particle has a diameter of $\approx 20 \mathrm{~nm}$ ) and the larger particles having (200 nm diameter) represent typical aggregates (they show a darker colour because of a higher concentration of particles in these aggregates). Small HAV aggregates (i.e., those with two spherical particles and $40 \mathrm{~nm}$ in diameter) were also detectable in the SWNT-PEI 0.2 nanocomposite (see Fig. 1b). In the same figure, it is possible to observe isolated HAV particles $\approx 20 \mathrm{~nm}$ in diameter because of the improved dispersion properties of HAV nanoparticles after their conjugation with the SWNT-PEI 0.2 nanocomposite. In fact, PEI creates a network around the nanotubes, where the viral particles become entrapped.

\subsection{Adsorption of HAV onto SWNTs}

SWNT-PEI and SWNT-COOH were obtained completely dried and were resuspended in different buffers. Among the buffers, complete PBS (phosphate buffered salts) (Merck, Milan, Italy), $0.2 \% \mathrm{NaCl}$, and $0.5 \% \mathrm{NaCl}$ caused the presence of visible clumps. The use of DMEM supplemented with $1 \%$ FCS provided homogenous and stable dispersion of SWNTs, as reported by Sager et al. (2007).

The influence on adsorption efficiency of different amounts of PEI on the SWNTs was evaluated. One hundred micrograms of SWNT-PEI 2.5, 1, 0.5, 0.2 and SWNT-COOH were incubated in ice for $15 \mathrm{~min}$, with $1.0 \times 10^{5}$ gen equiv. of HAV. All the tests showed an adsorption of the virus, but to different extents: SWNT-PEI 2.5 adsorbed $61 \%$ of the inoculum; SWNT-PEI 1, 68\%; SWNT-PEI $0.5,70 \%$; SWNT-PEI $0.2,43 \%$, and SWNT-COOH adsorbed only $21 \%$ (Fig. 2). The $\chi^{2}$ values showed no significant differences among SWNT-PEI 2.5, 1 and 0.5. However, significant differences were observed between SWNT-PEI 0.5, SWNT-PEI 0.2 and SWNT-COOH $(p<0.05)$.

\subsection{Rate of HAV adsorption by SWNTS}

Considering the previous results, the influence of time on HAV adsorption was evaluated. HAV at $1.0 \times 10^{5}$ gen equiv. was mixed (a)
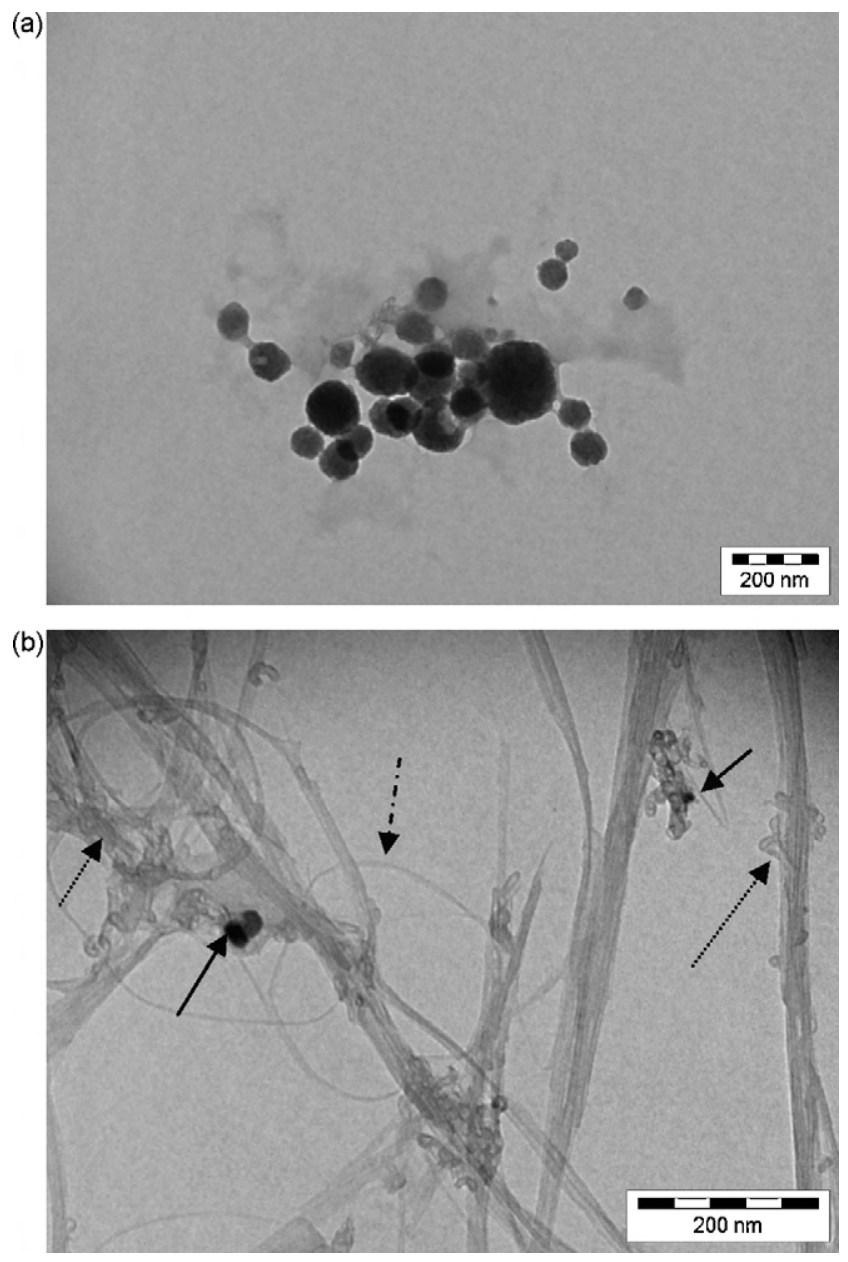

Fig. 1. TEM micrograph of HAV (a) and SWNT-PEI 0.2 conjugated with HAV (b). The continuous arrows indicate spherical HAV particles; the dotted arrows show the PEI coating on the carbon nanotubes; the dotted and continuous arrows indicate the single wall carbon nanotube bundles.

with $100 \mu \mathrm{g}$ of SWNT-PEI 0.2 or $100 \mu \mathrm{g}$ of SWNT-COOH for $0 \mathrm{~min}$ (T0), $15 \mathrm{~min}$ (T15), $30 \mathrm{~min}$ (T30) or $60 \mathrm{~min}$ (T60) in ice. All the assays were HAV-positive by qualitative RT-PCR. SWNT-PEI 0.2 adsorbed $27 \%$ of the inoculum at T0 $\left(4.7 \times 10^{4}\right.$ gen equiv. $\left./ \mathrm{ml}\right), 49 \%$ at T15 $\left(8.4 \times 10^{4}\right.$ gen equiv. $\left./ \mathrm{ml}\right), 11 \%$ at T30 $\left(1.8 \times 10^{4}\right.$ gen equiv. $\left./ \mathrm{ml}\right)$ and $30 \%$ at T60 $\left(5.0 \times 10^{4}\right.$ gen equiv. $\left./ \mathrm{ml}\right)$. SWNT-COOH adsorbed $4 \%$ at T0 $\left(6.6 \times 10^{3}\right.$ gen equiv. $\left./ \mathrm{ml}\right), 10 \%$ at T15 $\left(1.6 \times 10^{4}\right.$ gen equiv. $\left./ \mathrm{ml}\right), 20 \%$ at T30 $\left(3.4 \times 10^{4}\right.$ gen equiv. $\left./ \mathrm{ml}\right)$ and $6 \%$ at T60 $\left(1.0 \times 10^{4}\right.$ gen equiv./ml) (Fig. 3$)$. The $\chi^{2}$-test

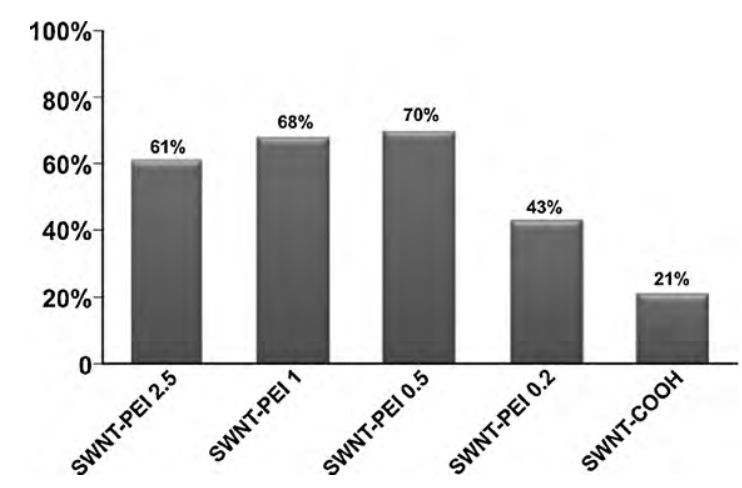

Fig. 2. Viral adsorption onto SWNTs functionalised with different amounts of PEI or SWNT-COOH. 


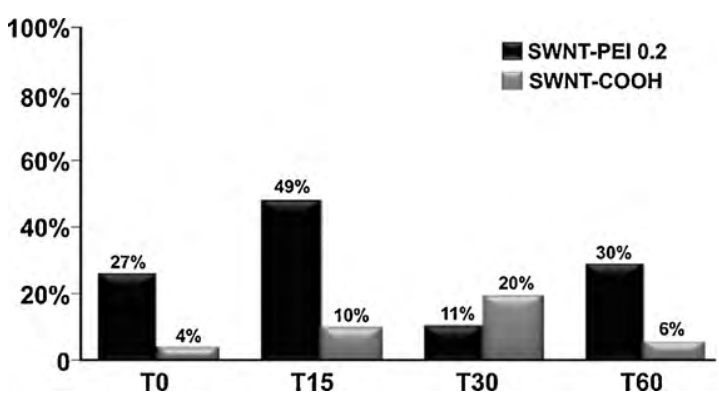

Fig. 3. HAV adsorption onto SWNT-PEI and SWNT-COOH at different times of contact.

revealed the significant differences among T30 SWNT-COOH and the other times of contact, whereas the results for all the SWNT-PEI were significant among them, although the values were variable.

\subsection{Adsorption of a fixed amount of $H A V$ with different amount of SWNT-PEI and SWNT-COOH}

To estimate the adsorptive capacity of the nanotubes in terms of number of gen equiv. associated, a fixed amount of HAV was mixed with $100 \mu \mathrm{l}$ of SWNT-PEI or SWNT-COOH at $100 \mu \mathrm{g}, 10 \mu \mathrm{g}, 1 \mu \mathrm{g}$, $100 \mathrm{ng}, 10 \mathrm{ng}, 1 \mathrm{ng}, 100 \mathrm{pg}, 10 \mathrm{pg}$, and $1 \mathrm{pg}$ and incubated for $15 \mathrm{~min}$ in ice. For SWNT-PEI 0.2, the RT-PCR results showed decreasing viral positivity for the $100 \mu \mathrm{g}, 10 \mu \mathrm{g}, 1 \mu \mathrm{g}, 100 \mathrm{ng}$ and $10 \mathrm{ng}$ amounts. In the remaining cases ( $1 \mathrm{ng}, 100 \mathrm{pg}, 10 \mathrm{pg}, 1 \mathrm{pg}$ ), only a light band was present. The titre of the viral control calculated with qRT-PCR was $2.2 \times 10^{5}$ gen equiv./test and the amount of adsorbed virus was expressed as percent virus adsorption relative to the positive control. SWNT-PEI 0.2 adsorbed $1.8 \times 10^{5}$ gen equiv. $(100 \mu \mathrm{g})$ (82\%), $6.4 \times 10^{4}$ gen equiv. $(10 \mu \mathrm{g})(31 \%), 1.6 \times 10^{5}$ gen equiv. $(1 \mu \mathrm{g})$ (73\%), $1.0 \times 10^{5}$ gen equiv. (100 ng) (45\%), $1.3 \times 10^{5}$ gen equiv. $(10 \mathrm{ng})(59 \%), 4.8 \times 10^{3}$ gen equiv. ( $\left.1 \mathrm{ng}\right)(2.2 \%), 1.0 \times 10^{4}$ gen equiv. $(100 \mathrm{pg}) \quad(4.5 \%), \quad 3.4 \times 10^{3}$ gen equiv. $\quad(10 \mathrm{pg}) \quad(1.5 \%)$ and $9.2 \times 10^{2}$ gen equiv. $(1 \mathrm{pg})(0.4 \%)$ (Fig. 4$)$.

\begin{tabular}{|c|c|c|c|c|}
\hline \multicolumn{5}{|c|}{ REAL TIME RT-PCR } \\
\hline & & CV gen.eq. & $\begin{array}{l}\text { Nr gen.eq. } \\
\text { adsorbed }\end{array}$ & $\begin{array}{l}\text { \% gen.eq. } \\
\text { adsorbed }\end{array}$ \\
\hline \multirow[t]{9}{*}{ SWNT-PEI 0.2} & $100 \mu \mathrm{g}$ & $2.2 \times 10^{5}$ & $1.8 \times 10^{5}$ & $82.0 \%$ \\
\hline & $10 \mu \mathrm{g}$ & & $6.4 \times 10^{4}$ & $31.0 \%$ \\
\hline & $1 \mu \mathrm{g}$ & & $1.6 \times 10^{5}$ & $73.0 \%$ \\
\hline & $100 \mathrm{ng}$ & & $1.0 \times 10^{5}$ & $45.0 \%$ \\
\hline & $10 \mathrm{ng}$ & & $1.3 \times 10^{5}$ & $59.0 \%$ \\
\hline & $1 \mathrm{ng}$ & & $4.8 \times 10^{3}$ & $2.2 \%$ \\
\hline & $100 \mathrm{pg}$ & & $1.0 \times 10^{4}$ & $4.5 \%$ \\
\hline & $10 \mathrm{pg}$ & & $3.4 \times 10^{3}$ & $1.5 \%$ \\
\hline & $1 \mathrm{pg}$ & & $9.2 \times 10^{2}$ & $0.4 \%$ \\
\hline \multirow[t]{9}{*}{ SWNT-PEI 0.5} & $100 \mu \mathrm{g}$ & $1.4 \times 10^{4}$ & $8.0 \times 10^{3}$ & $57.0 \%$ \\
\hline & $10 \mu \mathrm{g}$ & & $1.5 \times 10^{3}$ & $11.0 \%$ \\
\hline & $1 \mu \mathrm{g}$ & & $2.3 \times 10^{3}$ & $16.0 \%$ \\
\hline & $100 \mathrm{ng}$ & & $1.4 \times 10^{3}$ & $10.0 \%$ \\
\hline & $10 \mathrm{ng}$ & & $8.4 \times 10^{2}$ & $6.0 \%$ \\
\hline & $1 \mathrm{ng}$ & & $6.8 \times 10^{2}$ & $5.0 \%$ \\
\hline & $100 \mathrm{pg}$ & & $1.6 \times 10^{3}$ & $11.0 \%$ \\
\hline & $10 \mathrm{pg}$ & & $9.2 \times 10^{2}$ & $6.6 \%$ \\
\hline & $1 \mathrm{pg}$ & & $1.0 \times 10^{2}$ & $7.0 \%$ \\
\hline \multirow[t]{9}{*}{ SWNT-COOH } & $100 \mu \mathrm{g}$ & $5.6 \times 10^{4}$ & $1.0 \times 10^{3}$ & $1.7 \%$ \\
\hline & $10 \mu \mathrm{g}$ & & $1.9 \times 10^{3}$ & $3.3 \%$ \\
\hline & $1 \mu \mathrm{g}$ & & $3.7 \times 10^{3}$ & $6.6 \%$ \\
\hline & $100 \mathrm{ng}$ & & $6.0 \times 10^{3}$ & $10.7 \%$ \\
\hline & $10 \mathrm{ng}$ & & $1.0 \times 10^{4}$ & $17.8 \%$ \\
\hline & $1 \mathrm{ng}$ & & $2.0 \times 10^{4}$ & $35.7 \%$ \\
\hline & $100 \mathrm{pg}$ & & $8.0 \times 10^{3}$ & $14.2 \%$ \\
\hline & $10 \mathrm{pg}$ & & $1.4 \times 10^{4}$ & $25.0 \%$ \\
\hline & $1 \mathrm{pg}$ & & $1.2 \times 10^{4}$ & $21.4 \%$ \\
\hline
\end{tabular}

Fig. 4. Adsorption of HAV onto different amounts of SWNTs.
For SWNT-PEI 0.5 , the RT-PCR results showed viral positivity in all cases, and the titre of the viral control was $1.4 \times 10^{4}$ gen equiv./test. SWNT-PEI 0.5 adsorbed $8.0 \times 10^{3}$ gen equiv. $(100 \mu \mathrm{g})(57 \%), 1.5 \times 10^{3}$ gen equiv. $(10 \mu \mathrm{g})$ (11\%), $\quad 2.3 \times 10^{3}$ gen equiv. $(1 \mu \mathrm{g}) \quad(16 \%), \quad 1.4 \times 10^{3}$ gen equiv. (100 ng) (10\%), $8.4 \times 10^{2}$ gen equiv. (10 ng) (6\%), $6.8 \times$ $10^{2}$ gen equiv. ( $\left.1 \mathrm{ng}\right)(5 \%), 1.6 \times 10^{3}$ gen equiv. (100 pg) (11\%), $9.2 \times 10^{2}$ gen equiv. $(10 \mathrm{pg})(6.6 \%)$ and $1.0 \times 10^{2}$ gen equiv. $(1 \mathrm{pg})$ (7\%) (Fig. 4).

For SWNT-COOH, the RT-PCR results showed viral positivity for the $1 \mu \mathrm{g}, 100 \mathrm{ng}, 10 \mathrm{ng}, 1 \mathrm{ng}, 100 \mathrm{pg}, 10 \mathrm{pg}$ and $1 \mathrm{pg}$ amounts. In the remaining cases $(100 \mu \mathrm{g}, 10 \mu \mathrm{g})$ there were only slight traces of the virus. The titre of the viral control was $5.6 \times 10^{4}$ gen equiv./test. SWNT-COOH adsorbed $1.0 \times 10^{3}$ gen equiv. $(100 \mu \mathrm{g})(1.7 \%), 1.9 \times 10^{3}$ gen equiv. $(10 \mu \mathrm{g})$ (3.3\%), $3.7 \times 10^{3}$ gen equiv. $(1 \mu \mathrm{g})(6.6 \%), 6.0 \times 10^{3}$ gen equiv. (100 ng) (10.7\%), $1.0 \times 10^{4}$ gen equiv. (10 ng) (17.8\%), $2.0 \times 10^{4}$ gen equiv. ( $\left.1 \mathrm{ng}\right)(35.7 \%), 8.0 \times 10^{3}$ gen equiv. $(100 \mathrm{pg})$ (14.2\%), $1.4 \times 10^{4}$ gen equiv. (10 pg) (25\%) and $1.2 \times 10^{4}$ gen equiv. (1 pg) (21.4\%) (Fig. 4).

\section{Discussion}

The development of a nontoxic and highly efficient non-viral transfection system is one of the goals of future medicine. Several researchers (Nimesh et al., 2006; Chen et al., 2007) have shown efficient SWNT-mediated transfection of genes, proteins and nucleic acids into mammalian cells. Nanotubes have great therapeutic potential due to their physical and chemical features and to their ability to be activated for ad hoc uses. SWNTs have been evaluated as possible vectors for in vivo and in vitro delivery of genes, and proteins; however, to act as vectors, activation is necessary (Bivas-Benita et al., 2004; Godbey et al., 1999). Two sets of activated SWNTs were analysed: SWNT-COOH and SWNT-PEI. The ability to complex with whole viruses was demonstrated (Fig. 1a and b), thus opening the possibility of delivering entire virus particles into non-permissive cells that lack a specific receptor for the virus on the cell membrane. The interaction between both SWNT-PEI and SWNT-COOH and the virus is extremely rapid; the fastest recovery was $15 \mathrm{~min}$ for SWNT-PEI, whereas for SWNT-COOH it took $30 \mathrm{~min}$ (Fig. 3). Significant values were observed for SWNT-COOH T30.

The carboxylated SWNTs showed an adsorption not higher than $35.7 \%$ of the inoculum at $1 \mathrm{ng}$ of SWNTs (Fig. 4). Increasing the amount of SWNTs resulted in a progressive decrease in adsorption. This finding may be because enteric viruses, such as hepatitis $\mathrm{A}$, present a superficial negative charge at the neutral $\mathrm{pH}$ of the suspension media. Therefore, a partial electrostatic rejection between SWNT-COOH and the HAV particles (which are both negatively charged) might take place. Increasing the amount of SWNTs may increase the repulsion. When the contact time was increased, the amount of adsorption did not increase (Fig. 4). This electrostatic interaction is rapid and noticeable for SWNT-PEI but not for SWNT-COOH. At T0 the adsorption for SWNT-PEI was $27 \%$ versus $4 \%$ for SWNT-COOH (Fig. 3), keeping in mind that T0 corresponds to 3-5 min of contact (working delay).

SWNT-PEI has a higher adsorption than SWNT-COOH. PEI has a high positive charge density at neutral $\mathrm{pH}$ when it is present in an aqueous solution, and this facilitates the adsorption of negatively charged viruses. In 1991, Gajardo et al. (1991) used PEI to change electronegative glass powder into electropositive glass powder, thus increasing its virus adsorbing properties. Bivas-Benita et al. (2004) have clearly confirmed that the zeta potential of PEI adsorbed on poly (D,L-lactide-co-glycolide)-PLGA-polymers at a different ratio is strongly positive. The $\mathrm{Z}$ potential, upon interac- 
tion between PEI and virus, was still positive, although to a lower extent (personal data).

In a preliminary set of experiments, no particular differences in adsorption were evident among the different SWNT-PEI weight ratios ranging from $1: 2.5$ to $1: 0.5$ (Fig. 2), whereas significant differences were observed among SWNT-PEI 0.5, SWNT-PEI 0.2 and SWNT-COOH. Fischer et al. (1999) and Nimesh et al. (2006) have shown that the cytotoxicity of SWNT-PEI is dependent on the molecular weight and the amount of PEI. To reduce cell cytotoxicity and steric hindrance during the infection process, only the 1:0.2 ratio was investigated for future in vivo SWNT-PEI applications.

To explain the nucleic acid adsorption and the excess electropositive charges, Gautam et al. (2000), calculated that at the 1:0.5 weight ratio using $25 \mathrm{kDa}$ branched PEI, there are more nitrogen groups present on PEI than phosphate groups on DNA. In the experiments, the number of nitrogen groups was not calculated but the maximum adsorption was at 1:0.5 with $100 \%$ adsorption with up to $10^{4}$ gen equiv. in the inoculum and $92.5 \%$ with $10^{5}$ gen equiv. in the inoculum (personal data). Unlike SWNTs activated with carboxyl groups, PEI shows maximum adsorption at higher concentrations, from $100 \mu \mathrm{g}$ to $10 \mathrm{ng}$ (Fig. 4) for SWNT-PEI 0.2 and $100 \mu \mathrm{g}$ with SWNT-PEI 0.5. The need for a higher amount of SWNT-PEI with respect to carboxylate-SWNT may be due to the number of free nitrogen groups on PEI after the interaction with carboxyl groups. At $1 \mathrm{pg}$, SWNT-COOH shows an adsorptive activity twice that of SWNT-PEI (Fig. 4). A lower amount of carboxyl groups reduces the electrostatic rejection of the virus. With respect to the different concentrations, at each value, SWNT-PEI 0.2 gave significantly higher recovery than SWNT-PEI 0.5 or SWNT-COOH.

All the experiments were performed by re-suspending the SWNT-PEI in DMEM supplemented with 1\% FCS (Sager et al., 2007). The use of other buffers such as $0.5 \mathrm{M}$ PBS or $0.2 \mathrm{M} \mathrm{NaCl}$ caused evident clumps not easily resuspended in an ultrasonic bath. Additionally, the use of DMEM plus 1\% FCS is useful for possible future in vivo application with cell monolayers.

Fischer et al. (1999) showed that branched low molecular weight PEI was less cytotoxic as a transfection agent than high molecular weight PEI. Similar results were obtained by Boussif et al. (1995). The possibility of using SWNT-PEI (25 kDa) coupled to a virus as a transfection agent was suggested. As demonstrated by other researchers, the residual electropositive charge of PEI can result in adsorption onto negatively charged cellular membranes and increase intracellular uptake. In some experiments, the ability of fluorescein bound to SWNT-PEI to cross the cell barrier was demonstrated (personal data). The fluorescence was limited to the cytoplasm, as reported previously by Pantarotto et al. (2004).

To our knowledge, this is the first study describing the use SWNTs as carriers of human viruses. Recently, Brady-Estevez et al. (2008) showed that MS2 bacteriophages adsorb onto SWNTs, as no viral particles were detected at the filter outlet. However, no attempt was made to confirm the adsorption onto SWNTs. In this study, the binding of the virus was confirmed by RT-PCR and the amount of bound virus was determined by qRT-PCR.

In conclusion, this study demonstrates the binding of an enteric virus (the hepatitis A virus) to activated nanotubes.

The possibility of binding and introducing a virus into a non-permissive cell line to aid viral replication will offer better understanding of the molecular biology of the virus and a better way to evaluate the in vivo/in vitro evolution of the infection. Furthermore, it will help to provide sufficient amounts of virus to produce protective vaccines against non-replicating viruses. Single wall carbon nanotubes can also be used to remove viruses from various environmental matrices.

\section{References}

Bivas-Benita, M., Romeijn, S., Junginger, H.E., Borchard, G., 2004. PLGA-PEI nanoparticles for gene delivery to pulmonary epithelium. Eur. J. Pharm. Biopharm. 58, $1-6$.

Boussif, O., Lezoualc'h, F., Zanta, M.A., Mergny, M.D., Scherman, D., Demeneix, B. Behr, J.P., 1995. A versatile vector for gene and oligonucleotide transfer into cell in culture and in vivo: polyethylenimine. Proc. Natl. Acad. Sci. U.S.A. 92, 7297-7301.

Brady-Estevez, A.S., Kang, S., Elimelich, E., 2008. A single-walled-carbon-nanotube filter for removal of viral and bacteria pathogens. Small 4, 481-484.

Cai, D., Mataraza, J.M., Qin, Z.H., Huang, Z., Huang, J., Chiles, T.C., Carnahan, D., Kempa, K., Ren, Z., 2005. Highly efficient molecular delivery into mammalian cells using carbon nanotube spearing. Nat. Methods 2, 449-454

Chen, J., Tian, B., Yin, X., Zhang, Y., Hu, D., Hu, Z., Liu, M., Pan, Y., Zhao, J., Ki, H., Hou, C., Wang, J., Zhang, Y., 2007. Preparation, characterization and transfection efficiency of cationic PEGylated PLA nanoparticles as gene delivery systems. J. Biotechnol. 130, 107-113.

Donia, D., Divizia, M., Pana', A., 2005. Use of armored RNA as a standard to construct a calibration curve for real-time RT-PCR. J. Virol. Methods 126, 157-163.

Donia, D., Divizia, M., Panà, A., 2006. Problems related to the use of real-time RT-PCR in environmental analysis. Igiene Sanità Pubblica 62, 409-420.

Fischer, D., Bieber, T., Li, Y., Elsasser, H.P., Kissel, T., 1999. A novel nonviral vector for DNA delivery based on low molecular weight, branched polyethyleimine: effect of molecular weight on transfection efficiency and cytotoxicity. Pharm. Res. 16, 1273-1279.

Gajardo, R., Díez, J.M., Jofre, J., Bosch, A., 1991. Adsorption-elution with negatively and positively-charged glass powder for the concentration of hepatitis A virus from water. J. Virol. Methods 31, 345-351.

Gautam, A., Densmore, C.L., Xu, B., Waldrep, J.C., 2000. Enhanced gene expression in mouse lung after PEI-DNA aerosol delivery. Mol. Ther. 2, 63-70.

Godbey, W.T., Wu, K.K., Mikos, A.G., 1999. Size matters: molecular weight affects the efficiency of polyethylenimine as a gene delivery vehicle. J. Biomed. Mater. Res. 45, 268-275.

Kam, N.W.S., Jessop, T.C., Wender, P.A., Dai, H., 2004. Nanotube molecular transporters: internalization of carbon nanotubes-protein conjugates into mammalian cells. JACS 126, 6850-6851.

Klumpp, C., Kostarelos, K., Prato, M., Bianco, A., 2006. Functionalized carbon nanotubes as emerging nanovectors for the delivery of therapeutics. Biochim. Biophys. Acta 1758, 404-412.

Nimesh, S., Goyal, A., Pawar, V., Jayaraman, S., Kumar, P., Chandra, R., Singh, Y., Gupta, K.C., 2006. Polyethylenimine nanoparticles as efficient transfecting agents for mammalian cells. J. Control. Release 110, 457-468.

Pantarotto, D., Briand, J.P., Prato, M., Bianco, A., 2004. Translocation of bioactive peptide across cell membranes by carbob nanotubes. Chem. Commun. 7, 16-17.

Sager, T.M., Porter, D.W., Robinson, V.A., Lindsley, W.G., Schwegler-Berry, D.E., Castranova, V., 2007. Improved method to disperse nanoparticles for in vitro and in vivo investigation of toxicity. Nanotoxicology 1, 118-129.

Shim, M., Kam, N.W.S., Chen, R.J., Li, Y., Dai, H., 2002. Functionalization of carbon nanotubes for biocompatibility and biomolecular recognition. Nano Lett. 2, 285-288. 